\title{
MANAJEMEN PERUBAHAN SEKOLAH MENENGAH KEJURUAN DI KABUPATEN SLEMAN
}

\author{
Agus Susanto, Udik Budi Wibowo \\ Magister Manajemen Pendidikan UNY, Universitas Negeri Yogyakarta \\ agus_kartajaya@yahoo.com, udik_bw@uny.ac.id
}

\begin{abstract}
Abstrak
Artikel ini bertujuan untuk mendeskripsikan pengelolaan perubahan oleh pimpinan sekolah (kepala sekolah, wakil kepala sekolah, tim) dalam perubahan peningkatan mutu. Penelitian yang dilakukan menggunakan pendekatan kualitatif dengan desain etnografi tipe mikro. Analisis data menggunakan model Spradley meliputi: analisis domain, analisis taksonomi, dan analisis komponensial. Hasil analisis menunjukkan bahwa pengelolaan perubahan pada proses perencanaan, pengorganisasian, penggerakan, pengontrolan, dan pengevaluasian menjadi tugas utama/ tanggung jawab wakil kepala sekolah bidang kurikulum beserta tim. Strategi yang digunakan adalah empiris rasional dan power sharing dengan kebijakan yang dilakukan berupa pengembangan profesionalisme guru. Nilai-nilai yang dinyakini sebagai kesuksesan dalam keberhasilan perubahan adalah kedisiplinan guru dan siswa, motivasi guru dan siswa, komitmen guru dan siswa, dan budaya akademik yang terjaga.
\end{abstract}

Kata kunci: manajemen perubahan, manajemen strategik, mutu pendidikan

\section{THE CHANGE MANAGEMENT OF VOCATIONAL HIGH SCHOOL IN SLEMAN}

\author{
Agus Susanto, Udik Budi Wibowo \\ Magister Manajemen Pendidikan UNY, Universitas Negeri Yogyakarta \\ agus_kartajaya@yahoo.com, udik_bw@uny.ac.id
}

\begin{abstract}
This article aims to descripe the management of change by principals, vice-principals, dan team in managing change in schools. The method used is a qualitative research design ethnography with micro ethnography type. Analysis of data using Spradley's Model include domain analysis, analysis of taxonomic, and componential analysis. Results: the tasks of planning, organizing, actuating, controlling, and evaluating is the main task/responsibility of the vice principal and a team of curriculum areas. The strategy used is empirical and rational policy of power sharing that follow up with the professional development of teachers. The success values in the success of the change is the discipline of teacher and student, teacher and student motivation, commitment of teachers and students, academic culture is maintained.
\end{abstract}

Keywords: change management, strategic management, the quality of education 


\section{Pendahuluan}

Dewasa ini pendidikan di Indonesia mengalami berbagai perubahan yang $\mathrm{cu}$ kup besar. Perubahan tersebut antara lain: manajemen, kurikulum, dan sumber daya. Perubahan ini terjadi dikarenakan, salah satunya, reformasi 1998 yang menyentuh sendi-sendi pemerintahan negara. Dalam hal manajemen pendidikan, dewasa ini sekolah-sekolah negeri menggunakan sistem manajemen berbasis sekolah. Selain itu, perubahan mendasar terjadi dalam komponen kurikulum yakni dengan diterapkannya Kurikulum Berbasis Kompetensi (KBK) sampai Kurikulum 2013 (K-13). Demikian pula sumber daya manusia yang terlibat dalam proses pembelajaran mengalami perubahan dengan adanya desentralisasi pendidikan; sementara tingkat kesejahteraan para tenaga pendidik dan tenaga kependidikan juga semakin membaik.

Perubahan di level sekolah telah disikapi secara berbeda oleh warga sekolah. Pengertian warga sekolah secara sempit adalah kepala sekolah, guru, siswa dan karyawan. Kepala sekolah dapat menyikapi perubahan dengan melihatnya sebagai suatu kesempatan ataupun ancaman. Demikian juga guru, ada yang menyikapi perubahan sebagai kesempatan, peluang, ataupun ancaman. Dalam setiap perubahan akan ada yang pro dan kontra (status quo), ada yang cepat merespon dan lambat. Sebagian sekolah berhasil mengelola perubahan dan sebagian lainnya tidak. Berhasil tidaknya suatu perubahan tergantung dari banyak faktor, baik internal ataupun eksternal sekolah. Kepala sekolah sebagai manajer bertugas untuk mendesain dan mengawal perubahan agar didapatkan perubahan dari kondisi awal menjadi kondisi yang diharapkan.

Perubahan sekolah, dalam arti perubahan yang diinginkan, dituntut dalam peraturan perundangan yakni berupa Rencana Kerja Sekolah (RKS). Penyusunan RKS mengacu pada Peraturan Pemerintah Nomor 19 Tahun 2005 tentang Standar Nasional Pendidikan pada pasal 53 ayat 1 (Menteri Pendidikan Nasional, 2005), disebutkan bahwa "setiap satuan pendidikan dikelola atas dasar rencana kerja tahunan yang merupakan penjabaran rincidari rencana kerja jangka menengah satuan pendidikan yang meliputi masa 4 (empat) tahun". Peraturan lain yakni Permendiknas No. 19 Tahun 2007 tentang Standar Pengelolaan Pendidikan pasal 1 ayat (1) (Menteri Pendidikan Nasional, 2007) "setiap satuan pendidikan wajib memenuhi standar pengelolaan pendidikan yang berlaku secara nasional". Hal ini sebagai konsekuensi dari kebijakan penerapan manajemen berbasis sekolah sesuai amanat Undang-Undang Sisdiknas pasal 51.

Kepala sekolah menengah kejuruan (SMK), khususnya SMK kelompok Bisnis dan Manajemen, memegang fungsi yang sangat besar dalam memajukan sekolah dengan kompetensi manajerial dan kewirausahaan. Kepala sekolah mempunyai peran sebagai manajer, entrepreneur, supervisor, pendidik dan teladan bagi warga sekolah. Peran-peran yang diemban tersebut harus mampu dijalankan oleh kepala sekolah. Usman (2006) menegaskan kepala sekolah harus dapat memanfaatkan sumber daya sekolah yakni 7M+1i (Man, Money, Machine, Method, Material, Market, Minute and information). Pada kenyataannya kepala sekolah masih belum optimal dalam mendayagunakan berbagai sumber daya untuk mengelola perubahan.

Ada berbagai macam indikator kualitas lulusan, diantaranya nilai ujian nasional (UN) dan keterserapan lulusan sekolah dalam dunia kerja. Selama praktek persekolahan dapat diketahui kadang suatu target dapat tercapai atau tidak. Pada 2014, SMK$\mathrm{N}-\mathrm{A}$ memiliki dua mata pelajaran yang tidak tercapai target nilai UN-nya, yakni bahasa Inggris dan Matematika. Dua mata pelajaran ini tidak tercapai karena berbagai macam faktor yakni dari input, proses pembelajaran, maupun faktor eksternal lain.

Perubahan demi perubahan akan selalu terjadi di dunia ini, tidak terkecuali di sekolah. Dengan mempelajari bagaimana pengelolaan perubahan yang diperinci dari tahapan, strategi, pemberdayaan staf serta stakehoders sekolah maka akan dapat me- 
mahami atau menemukan pola yang digunakan oleh manajemen sekolah dalam mengelola perubahan. Cheng (1996, p. 173) menjelaskan bahwa proses manajemen perubahan melalui tiga tahap yakni: unfreezing (pencairan), changing (perubahan) dan refreezing (pemantapan).

Goksoy (2013, p. 189) menjelaskan definisi manajemen perubahan "management of change is an administration process which foresee continious change and provides to use it for corporate purposes". Manajemen perubahan adalah proses administrasi yang mendesain perubahan secara kontinyu untuk mencapai tujuan organisasi. Definisi lain tentang manajemen perubahan dikemukakan oleh Creasey (2007, p. 3)berikut.

...is the process, tools and techniques to manage the people-side of change to achieve the required business outcome. Change management incorporates the organizational tools that can be utilized to help individuals make successful personal transitions resulting in the adoption and realization of change.

Pengelolaan perubahan mendorong munculnya kompetensi manajerial, yakni kompetensi yang harus dipunyai seorang manajer. Salah satu kompetensi manajerial yang terkait dengan perubahan adalah manajemen perubahan. Manajemen perubahan memerlukan pemahaman dan penguasaan tentang leadership dan managership. Leadership dibutuhkan untuk memicu dan memacu perubahan yang telah direncanakan kemudian tugas manajerial (managership) yang melakukan penyelarasan perubahan yang dipacu (Mulyadi, 1997, p. 236). Kedua tugas ini harus dapat dilaksanakan secara selaras dan sukses agar perubahan yang terjadi sesuai dengan apa yang telah direncanakan atau sesuai harapan stakeholders.

Kompetensi manajemen perubahan seringkali disebut komponen sentral dari kepemimpinan. Hal ini beralasan, karena tugas pemimpin adalah bagaimana menjaga agar organisasi dapat eksis di tengah perubahan. Hal ini menunjukkan adanya perbedaan tugas antara manajer dengan pemimpin dalam mengelola perubahan.
Perbedaan lain antara pemimpin dan manajer dapat dilihat pada Tabel 1.

Tabel 1. Perbedaan Fokus Pemimpin dan Manajer

\begin{tabular}{ll}
\hline Pemimpin fokus pada & \multicolumn{1}{c}{$\begin{array}{c}\text { Manajer fokus } \\
\text { pada }\end{array}$} \\
\hline Visi & Implementasi \\
Isu stratejik & Isu operasional \\
Transformasi & Transaksi \\
Tujuan & Maksud \\
Orang-orang & Sistem \\
Mengerjakan hal yang & Mengerjakan \\
benar & dengan benar \\
\hline
\end{tabular}

Sumber: (West-Burnham, 1997, p. 117)

Perubahan akan dapat terjadi apabila terpenuhi adanya komponen-komponen perubahan yang meliputi: visi, skill, insentif, sumber daya, dan program (Zamroni, 2007 , p. 21). Apabila salah satu tidak terpenuhi, misalnya insentif tidak atau kurang terpenuhi, maka akan terjadi perubahan juga namun perubahan akan berlangsung lamban. Jika sekolah telah memiliki visi, skill, insentif, sumber daya, dan program maka akan terjadi perubahan. Sekolah yang telah menjalankan otonomi sekolah sudah memiliki visi misi yang dikembangkan melalui program capacity building di era 2000-an. Artinya, dengan adanya kebijakan desentralisasi pendidikan melalui manajemen berbasis sekolah maka proses perubahan menuju pada pencapaian tujuan lebih memungkinkan.

\section{Metode Penelitian}

Penelitian ini menggunakan pendekatan kualitatif dengan desain etnografi. Tipe etnografi yang digunakan adalah mikro (Creswell, 2012, p. 464). Penelitian dilakukan di Sekolah Menengah Kejuruan Swasta A di Pakem (dengan inisial SMKSA), Sekolah Menengah Kejuruan Swasta di Turi (SMKS-B), dan Sekolah Menengah Kejuruan Negeri (SMKN) di Depok, wilayah Kabupaten Sleman. Pelaksanaan penelitian dimulai bulan Januari sampai Mei 2015. Sumber data penelitian ini meliputi: kepala sekolah, anggota panitia/pokja UN, guru, 
dan siswa. Team agent of change adalah tim yang ditunjuk kepala sekolah untuk menyukseskan perubahan, yang dapat terdiri dari: wakil kepala sekolah, guru, karyawan, siswa, ataupun tokoh masyarakat.

Data penelitian ini berupa data kualitatif. Teknik pengumpulan data yang digunakan meliputi wawancara, observasi, dan analisis dokumen. Instrumen penelitian adalah peneliti yang dibantu dengan pedoman wawancara dan pedoman observasi. Analisis data secara lengkap menggunakan model yang telah dikemukakan oleh Spradley (Creswell, 2012, p. 487). Analisis data etnografi model Spradley meliputi: analisis domain, analisis taksonomi, analisis komponensial dan analisis tema budaya. Tipe etnografi yang digunakan penelitian ini adalah etnografi mikro sehingga memungkinkan untuk tidak memakai semua tahapan dalam diagram alir model Spradley. Tahapan yang tidak dilakukanadalah mencari tema budaya. Creswell (2012, p. 483) menjelaskan bahwa analisis tema budaya digunakan untuk etnografi realis.

\section{Hasil Penelitian dan Pembahasan}

\section{Hasil Penelitian}

\section{Profil SMKS-A}

Visi SMKS-A adalah menghasilkan lulusan dengan kecerdasan spiritual, intelektual dan emosional yang mantap, demi menyongsong kehidupan dunia dan akhirat yang penuh barokah Alloh SWT. Visi tersebut yang merupakan konsep mutu yang ingin diwujudkan sekolah untuk para siswa atau lulusannya.

Program peningkatan mutu di SMKSA secara jangka pendek salah satunya adalah adanya kenaikan nilai UN dari ratarata C menjadi B-. Nilai rata-rata UN sekolah adalah sebesar 5,33 pada 2013 kemudian ditargetkan meningkat menjadi ratarata 5,60 pada 2015. Isu perubahan yang ingin digali melalui tulisan ini adalah manajemen perubahan nilai UN dari ratarata sekolah 5,33 menjadi 5,60.

Profil SMKS-B
Slogan sekolah adalah unggul dan islami. Pendiri sekolah mengharapkan tamatan sekolah ini memiliki keunggulan dalam bidang akademik dan sekaligus memiliki wawasan agama yang baik (integrated). Sekolah ini terus menginginkan peningkatan prestasi akademik yang dapat diukur dari nilai UN. Disamping peningkatan prestasi akademik, sekolah menetapkan minimal siswa telah hafal 1 juz Al Quran sebelum dinyatakan lulus.

Simbol budaya yang sangat nampak dari sekolah adalah adanya pesantren yang terintegrasi dengan sekolah. Bangunan sekolah didesain seperti pesantren modern. Siswa setiap Senin sampai Sabtu bersekolah pada jam 7.00 sampai 14.30, kemudian dilanjutkan sebagai santri pada jam 15.30 sam-pai 21.00, dan subuh sampai jam 6.00. Aktivitas seperti ini mereka lakukan dari hari Minggu sampai Jumat, sedangkan hari Sabtu kegiatan pesantren libur. Siswa memang tinggal di asrama sekolah sehingga tidak kesulitan melakukan aktivitas seperti itu.

Simbol budaya juga dapat diketahui dari bentuk atap sekolah yang berbentuk kubah. Kubah di atap sekolah ini membuat gedung terlihat seperti bangunan masjid. Terdapat dua buah kubah berwarna hijau muda kekuningan yang mudah dikenali dan dapat terlihat dari kejauhan. Benda berupa kubah merupakan simbol kehidupan Islami yang kental. Dinding sekolah memiliki cat yang dominan warna hijau juga merupakan simbol dari kehidupan Islami yang ingin dikembangkan di sekolah ini. Warna hijau identik dengan agama Islam.

Program peningkatan mutu sekolah adalah meningkatkan prestasi UN dari rata-rata sekolah B- menjadi B pada 2016. Program ini disebut sebagai program jangka pendek (3 tahun), sedangkan tujuan mutu jangka panjang adalah menjadi sekolah swasta lokal yang unggul dan diperhitungkan di tingkat regional (DIY) dan nasional.

\section{Profil SMKN}

Kebijakan mutu SMKN subjek penelitian memiliki singkatan atau akronim yang berarti satu tujuan, menyongsong masa de- 
pan, erat dalam persaudaraan, kuat menghadapi tantangan, aktif meninjau sistem manajemen mutu secara berkelanjutan; selain itu dinamis dalam bekerja, enyahkan segala rintangan, satukan tekad, tanggung jawab dalam bekerja, dan ayo kita maju.

SMKN ini memiliki definisi mutu jangka pendek, sebagai prioritas, yakni peningkatan nilai UN. Selama ini, diketahui orang tua siswa cukup kritis untuk bertanya berapa nilai UN yang didapatkan sekolah tahun terakhir. Hal ini membuat sekolah yang berorientasi pelanggan untuk membuat kebijakan memprioritaskan nilai UN.

Pengelolaan Perubahan

Pengelolaan perubahan pada tahap unfreeze diisi dengan kegiatan kepala sekolah beserta tim sekolah melakukan sosialisasi akan pentingnya perubahan. Tahap changing diisi dengan program-program peningkatan target nilai UN. Program yang dijalankan yakni: penambahan materi dan jam untuk tiga pelajaran (Bahasa Indonesia, Bahasa Inggris, dan Matematik), tryout UN, melakukan achievement motivation training, dan program tutor teman sebaya. Tahap refreezing diisi dengan pemberian rewards berupa apresiasi maupun syukuran dari pimpinan sekolah untuk tim yang terlibat dalam proses perubahan.

Program peningkatan mutu berupa les tambahan kepada siswa diberikan pada saat jam pelajaran reguler berlangsung, ada juga sekolah yang memberikannya setelah program belajar mengajar selesai. Jam pelajaran dalam proses belajar mengajar secara reguler berlangsung pada jam 7.00-14.00, sedangkan tambahan pelajaran di sore hari berlangsung pada jam 14.30 sampai 16.00 . Jam tambahan untuk program peningkatan nilai UN ini hanya diberikan untuk mata pelajaran yang di-UN-kan saja.

Tujuan dalam pencapaian target nilai UN sudah sangat jelas ditetapkan. Nilai UN berbentuk angka yang mudah untuk dipahami oleh semua warga sekolah. Akan tetapi tidak semua warga sekolah telah mengetahui tujuan ataupun target yang telah ditetapkan ini, khususnya siswa. Guru yang bukan mengajar mata pelajaran yang di-
UN-kan serta siswa umumnya tidak mengetahui adanya perubahan ini.

\section{Target Perubahan}

Target perubahan nilai UN untuk SMKS-A adalah rata-rata $B$ pada tahun ajaran 2016/2017. Target perubahan nilai UN untuk SMKN-B adalah rata-rata C pada tahun ajaran 2015/2016. Adapun target perubahan nilai UN untuk SMKN adalah rata-rata 9,30 untuk mata pelajaran bahasa Indonesia, mata pelajaran bahasa Inggris 7,72, dan Matematika 8,69.

Target tersebut diproyeksikan dari pencapaian rata-rata sekolah pada tahun sebelumnya. Pencapaian nilai UN tahun sebelumnya untuk SMKS-A adalah rata-rata D pada tahun ajaran 2012/2013. Pencapaian nilai UN tahun sebelumnya untuk SMKS-B adalah rata-rata B- pada tahun ajaran 2012/2013, dan B- pada tahun ajaran 2013/2014. Pencapaian nilai UN tahun sebelumnya untuk SMKN adalah rata-rata 8,75 untuk bahasa Indonesia, bahasa Inggris 7,70, dan Matematika 8,54 pada tahun ajaran 2013/2014.

\section{Penggunaan Sumber Daya Sekolah}

Organisasi sekolah terus berusaha untuk mengejar dan mendayagunakan sumber daya untuk mendapatkan kinerja yang maksimal. Sumber daya yang digunakan untuk peningkatan mutu diantaranya: sumber daya manusia, fasilitas, serta anggaran. Sumber daya manusia di SMKN sebanyak 60 orang guru PNS dimana 90\% sudah memiliki sertifikat pendidik. SMKSA memiliki total 15 guru dimana delapan orang PNS dimana delapan orang atau 53\% guru telah bersertifikat pendidik. SMKS-B memiliki total 19 guru dimana lima orang atau $26 \%$ guru telah bersertifikat pendidik.

Fasilitas sekolah berupa perpustakaan, dan koneksi internet telah tersedia secara cukup di tiga sekolah tersebut. Untuk fasilitas pembelajaran di kelas berupa LCD projector baru SMKN yang memasang projector di tiap kelas. Fasilitas pembelajaran berupa projector untuk dua SMK yang lain juga tersedia tetapi tidak di semua kelas. 
Anggaran (APBS) yang dimiliki sekolah negeri lebih tinggi dibandingkan sekolah swasta. SMKN memiliki anggaran yang berasal dari APBN, APBD provinsi, dan APBD kabupaten, ditambah dari orang tua siswa (komite sekolah). Sekolah swasta seperti SMKS-A dan SMKS-B hanya mengandalkan dari dana BOS yang berasal dari APBN. Pada sekolah swasta sumber dana dari komite sekolah sangat minim karena siswa banyak yang berasal dari keluarga prasejahtera dan tidak mampu membayar biaya pendidikan.

Berdasarkan kepemilikan sumber daya yang ada nampak bahwa sekolah yang telah mapan memiliki sumber daya yang lebih baik dibandingkan sekolah lain. Sekolah swasta yang terakreditasi A ternyata memiliki sumber daya guru bersertifikat lebih sedikit dibandingkan swasta yang terakreditasi B. Hal ini terjadi karena untuk sekolah swasta yang terakreditasi A usia sekolahnya lebih muda dibandingkan sekolah yang terakreditasi B. Sekolah SMK swasta yang terakreditasi B memiliki guru PNS yang dipekerjakan yakni sebanyak delapan orang guru, sedangkan SMK swasta dengan akreditasi A baru memiliki empat orang guru bersertifikat termasuk kepala sekolah.

Output dari pemakaian sumber daya ini justru menunjukkan hasil yang tidak berbanding lurus. Pada sekolah yang terakreditasi A menghasilkan nilai UN siswa dengan rata-rata $\mathrm{B}-$, sedangkan pada sekolah yang terakreditasi B baru mencapai nilai rata-rata UN predikat C. Hal ini menunjukkan bahwa jumlah guru yang bersertifikat belum menjamin pencapaian nilai UN yang lebih tinggi.

\section{Hambatan Perubahan}

Hambatan yang dialami oleh warga sekolah diantaranya adalah masih adanya guru favorit dan non favorit di kalangan siswa, ini ditemui di SMKN. Bagi guru yang favorit, pelajaran yang diajarkan oleh guru menjadi mudah dicerna. Karena mudah dicerna maka peningkatan mutu (nilai UN) akan menjadi lebih mudah tercapai. Guru favorit dan tidak favorit ini tidak terlepas dari kemampuan guru sendiri untuk dapat menerangkan materi pada siswa. Hal ini diakui oleh siswa dimana ada saja guru yang tidak nge-dong-i saat menerangkan materi pembelajaran di depan kelas. Guru yang cara mengajarnya dianggap enak oleh siswa, mudah dimengerti, akrab dengan siswa, sabar, dan greteh adalah guru yang difavoritkan siswa.

"SDM-nya terbatas. Kadang-kadang untuk ... untuk les, diperlukan eeee .... orang yang mau greteh ke siswa. Nah ... tidak semua guru matematika greteh ke siswa". (C/1).

Hambatan lain adalah minimnya inovasi pembelajaran yang dilakukan guru. Mereka sudah mendapatkan berbagai pelatihan pembelajaran tetapi pada penerapannya di depan kelas telah mengalami berbagai macam hambatan. Hambatan yang muncul adalah disebabkan oleh sarana dan prasarana pembelajaran yang masih terbatas di sekolah, dan kurang tersedianya dana.

Hambatan lain yang ditemukan adalah adanya resistensi dari guru, hal ini ditemui di SMKS-B dan SMKN. Meski demikian, resistensi yang ada tidak besar sehingga dapat disebut minim akan resistensi. Jika pun ada resistensi, hal itu tidak menghalangi proses eksekusi program secara signifikan. Bahkan mereka ikut berubah juga meski resisten terhadap perubahan.

“... Kalau sekolah punya kebijakan seperti ini, dia seragam ... bareng gitu lho. Hanya pada ngomong aja kok. Kalau ada program sekolah ya tetep jalan kok. Tetep jalan. Yo paling ada yang beberapa ajak-ajak untuk tidak ikut secara full atau maksimal ". (C/6).

Faktor penghambat berikutnya yang dialami oleh semua sekolah yakni kurangnya jam untuk mempersiapkan diri. Hambatan ini terjadi karena banyaknya beban kerja guru. Guru yang mengajar mata pelajaran UN terkadang diambil jamnya karena kegiatan lain sehingga harus mengganti di kesempatan yang berbeda. Sebagai contoh pada bulan Februari itu siswa di- 
konsentrasikan untuk ujian ketrampilan selama satu bulan penuh. Berikut keterangan informan.

\section{"Jadi misalnya target bisa mengajar ini sudah pada tahu ternyata habis dipakai untuk acara apa ... itu kan menghambat juga tho. Ya targetnya nggak terpenuhi. Ada satu kelas itu sampai nggak ketemu ... karena yang Unas itu tergangu ujian kejuruan misalnya". (C/6).}

Mutu pendidikan sekolah banyak dipengaruhi oleh input siswa. Semakin input siswa yang masuk ke sekolah itu baik, akan diikuti dengan output yang baik pula. Proses pembelajaran di semua sekolah hampir sama, tetapi siswa yang memiliki input baik dapat lebih aktif dan mandiri dalam belajar sehingga tidak tergantung guru. Mereka mampu belajar secara mandiri sehingga guru dan sekolah tinggal memfasilitasi atau mengarahkan siswa sesuai potensi yang dimiliki.

Sebagai contoh, untuk siswa di SMK$\mathrm{N}$, mereka dapat menjalankan kegiatan tutor teman sebaya dan aktif mengajukan diri dalam berbagai perlombaan. Seperti disebutkan oleh informan, bahwa sering kali siswa mengikuti suatu perlombaan tanpa diminta oleh guru. Siswa yang mendapatkan informasi suatu perlombaan langsung menemui guru untuk dibimbing mengikuti suatu perlombaan.

Mutu sekolah juga dikembangkan secara berkelanjutan dengan menjaga kultur pembelajaran. Kultur pembelajaran adalah budaya yang ditanamkan oleh sekolah agar siswa terpacu untuk menjadi yang terbaik. Siswa di SMKN terbiasa untuk mencari tahu jika ada pengetahuan yang belum tahu. Mereka dapat bertanya suatu materi pelajaran pada guru ataupun sesama siswa. Jika ada yang belum diketahui, maka mereka akan berusaha untuk belajar sendiri atau meminta teman untuk diajari.

Berdasarkan hasil penelitian diketahui faktor penentu keberhasilan peningkatan mutu adalah kualitas input siswa, kemandirian belajar dan kepercayaan diri siswa, kultur pembelajaran yang terbentuk di sekolah, kemampuan dan komitmen guru. Faktor-faktor itu adalah yang membedakan sekolah yang memiliki mutu yang baik dibandingkan mutu sekolah yang kurang.

Konsep mutu yang berbeda antar sekolah ini menunjukkan bahwa adanya keinginan sekolah untuk memberikan nilai tambah (value added) bagi lulusannya. Ada sekolah yang menekankan lulusan yang profesional sesuai dengan bidang keahliannya, tetapi sekolah lain ada yang tidak hanya menghasilkan lulusan yang mampu secara akademis saja, tetapi memiliki akhlaq secara islami, sementara sekolah lain ingin menekankan bekal ketrampilan bagi lulusannya. Tujuan-tujuan tersebut merupakan nilai tambah yang diberikan sekolah. Nilai tambah dalam dunia pendidikan ini merupakan konsep yang dikenal dalam manajemen strategik. Untuk dapat bersaing dengan sekolah lain, maka sekolah harus membuat diferensiasi dengan sekolah lain. Tidak ada sekolah yang dapat unggul di segala sektor pendidikan, sehingga diperlukan pemfokusan usaha dalam hal mutu aspek tertentu.

Konsep diferensiasi dikenal dalam istilah marketing. Dalam konsep diferensiasi terkandung suatu strategi. Hal ini sesuai dengan pendapat Porter (1996, p. 64) "the essence of strategy is choosing to perform activities differently than rivals do". Inti dari strategi adalah memilih untuk menghasilkan aktivitas yang berbeda dengan yang dilakukan oleh kompetitor. Konsep yang lebih umum banyak dipahami adalah keunggulan kompetitif (competitive advantages).

Adanya perbedaan keunggulan yang ditawarkan oleh tiga sekolah tersebut merupakan bentuk dari upaya mencapai keunggulan kompetitif. Keunggulan tiap sekolah mencoba ditawarkan pada para siswa agar ikut bergabung, sekaligus bagi pemberi kerja yang mendapatkan sentuhan value yang diberikan oleh sekolah pada para siswanya. Value adalah nilai tambah yang diberikan untuk suatu produk. Untuk menghasilkan suatu value, manajer bertugas melakukan analisis internal sekolah (sumber daya dan kemampuan) untuk da- 
pat memanfaatkan peluang yang ada serta berusaha meminimalkan hambatan.

Salah satu cara mendapatkan keunggulan kompetitif adalah melakukan analisis yang disebut strenght-weakness-opportunity-threats (SWOT) (Barney, 1995, p. 49). Sekolah-sekolah dewasa ini juga sudah membuat perencanaan strategik seperti termuat dalam Rencana Pengembangan Sekolah (RPS). Dalam dokumen tersebut, sekolah sebelum menyusun visi, misi, sasaran, model, dan kerangka kerja akan melakukan analisis SWOT.

Berdasarkan hasil pengumpulan data diketahui setiap sekolah sudah memiliki visi yang jelas untuk dituju. Visi berfungsi sebagai penunjuk arah bagi semua warga sekolah. Skill adalah kualifikasi yang diharapkan untuk mensukseskan suatu perubahan. Skill guru diakui dengan adanya kualifikasi pendidikan yang telah diselesaikan di tingkat perguruan tinggi sesuai tuntutan peraturan perundangan. Ada sebagian guru yang telah mendapatkan sertifikat pendidik serta sertifikat asesor PKG, dimana di SMKN terdapat 10 guru asesor PKG bersertifikat.

Sumber daya yang dimiliki sekolah cukup bervariasi. Ada yang merasa perlu menggunakan sumber daya dari luar sekolah, sementara ada yang memanfaatkan seadanya, dan ada yang dapat memilih dari sumber daya yang dimiliki sekolah. Sumber daya anggaran juga berbeda antara satu sekolah dengan sekolah yang lainnya.

Insentif selama ini diidentikkan oleh guru dengan tunjangan dalam bentuk uang. Hampir setiap guru memiliki pandangan yang berbeda tentang insentif dalam bentuk uang. Pada umumnya seorang guru di sekolah swasta lebih memiliki keikhlasan soal insentif dibandingkan guru di sekolah negeri atau pegawai negeri. Sertifikasi juga belum dianggap sebagai insentif untuk meningkatkan mutu pendidikan (pembelajaran).

Guru di sekolah swasta sudah menyadari konsekuensi dari pekerjaan yang dijalaninya. Mereka memiliki pandangan hidup yang juga cerminan budayanya, way of life, bahwa bekerja adalah ibadah dimana guru bekerja untuk Tuhan. Berikut keterangan dari informan.

"Bagi saya itu kerja yang penting asal ikhlas itu Tuhan pasti membalas. Kita jangan memandang untuk manusia, tapi kita kerja untuk Tuhan. Nah itu rata-rata pasti enak. Kita ndak tau nanti Tuhan memberi jalan, memberi rizki. Tapi kadang orang kerja hanya untuk orang. Kita kalo bekerja punya tendensi. nak ono duite yo nyambut gawe, nak ora yo ora". (A/1).

Berdasarkan keterangan informan A/1 diketahui bahwa guru dalam bekerja itu jangan hanya berorientasi uang. Kalau ada uang mau menjalankan tugas tetapi kalau tidak ya tidak mau menjalankan. Rejeki itu tidak hanya berupa uang tetapi bisa dalam bentuk lain. Rejeki uang pun banyak jalan dan tempatnya, tidak hanya dari hasil mengajar atau kegiatan yang dilaksanakan di sekolah saja.

Program yang dirancang oleh sekolah untuk mensukseskan perubahan hampir sama yakni pemberian jam pelajaran tambahan untuk tiga mata pelajaran, dan pemberian tugas bagi siswa (PR). Perbedaan yang terlihat dari tiga sekolah tersebut adalah tentang skill, sumber daya, insentif. Sekolah yang mapan cenderung memiliki komponen perubahan yang lebih lengkap dibandingkan sekolah lain.

Komponen lain yang penting dalam kesuksesan perubahan adalah kepemimpinan. Hal ini dapat dilihat pada SMKN dimana perubahan lebih berhasil dibanding sekolah lain. Pemimpin sekolah berusaha untuk melakukan pengembangan organisasi dan komunikasi yang baik pada seluruh warga sekolah. Adanya tuntutan perubahan dalam struktur berimplikasi pada perubahan figur dan kultur.

Berdasarkan data tiga sekolah diketahui ada sekolah yang sukses mencapai target yang ditetapkan dan sekolah yang tidak berhasil mencapai target. Sekolah yang mencapai target adalah SMKS-A, sedangkan sekolah yang tidak mencapai target adalah SMKN dan SMK-B. Ketika dilakukan wawancara terhadap kepala sekolah SMKS-A nampak sekali ambisi sekolah un- 
tuk meningkatkan mutu sekolahnya. Sekolah ingin menjadi sekolah kejuruan yang terdepan di tingkat wilayah sehingga agresif dalam berusaha mencapai target pencapaian nilai. Pada sisi lain, SMKN yang sudah memiliki rata-rata nilai UN tinggi tidak tampak memiliki agresifitas dalam memperjuangkan targetnya. Hal ini nampak pada kesempatan wawancara dengan kepala sekolah dan wakil yang meski mematok target tetapi tidak diikuti semangat berapi-api.

Meskipun dari nilai UN tertinggi didapatkan oleh SMKN, tetapi ternyata ada dua mata pelajaran yang tidak tercapai target nilai UN-nya. Berdasarkan hasil wawancara guru di sekolah menganggap intake siswa adalah faktor utama prestasi sehingga tidak memacu usaha guru agar efektivitas belajar tercapai. Apa yang dikerjakan oleh guru bidang studi masih sama dengan apa yang dilakukannya tahun lalu.

Faktor keberhasilan dari setiap sekolah ditemukan berbeda-beda. Guru yang disiplin dan sarana prasarana diakui sebagai faktor yang mendukung keberhasilan perubahan di SMKS-B. Motivasi guru dan siswa (SDM), serta fasilitas merupakan faktor kunci keberhasilan di SMKS-A, sedangkan komitmen guru dan siswa adalah faktor kunci keberhasilan perubahan.

Penamaan tim sekolah tidak seragam untuk sekolah sampel, yakni di SMKS-B memakai istilah kelompok kerja, di SMKSA menggunakan istilah panitia $\mathrm{UN}$, dan SMKN juga memakai istilah panitia UN. Pembentukan tim di SMKS-A dan SMK-B langsung dilakukan oleh kepala sekolah dengan menunjuk guru, sedangkan di SMKN dimulai dengan penjaringan yang dilakukan oleh wakil kepala sekolah bidang kurikulum kemudian diusulkan pada kepala sekolah. Kepala sekolah yang selanjutnya akan menetapkan siapa guru yang terlibat langsung pada proses perubahan.

Keberhasilan perubahan dari tiga sekolah yang masuk dalam kategori lamban. Menurut informan hal ini terjadi karena adanya insentif yang masih dirasakan kurang. Sekolah sudah memiliki visi, kete- rampilan/kompetensi, sumber-daya, dan program untuk memungkinkan terjadinya perubahan, tetapi kurangnya insentif membuat perubahan menjadi lamban. Sebagian sekolah telah menggunakan instrumen sertifikasi guru untuk meningkatkan insentif, akan tetapi karena kuota yang terbatas maka tidak semua guru untuk mata pelajaran yang di-UN-kan diajukan mendapatkan sertifikasi. Sertifikasi di sekolah lebih diprioritaskan pada senioritas guru, bukan pada prestasi yang didapatkan atau tanggung jawab yang dibebankan pada guru.

Tentang komitmen manajemen puncak pada proses perubahan tidak semua sekolah memiliki komitmen yang penuh. Komitmen tertinggi didapatkan dari kepala sekolah SMKS-A yang menganggap nilai UN merupakan prioritas karena menjadi perhatian masyarakat. Jika nilai UN baik maka masyarakat akan menganggap sekolah sebagai sekolah yang bermutu sehingga meningkatkan kepercayaan masyarakat pada sekolah. Berbeda dengan SMK-B yang menganggap nilai UN bukanlah prioritas utama tetapi harus seimbang dengan keterampilan yang dimiliki siswa. Hasil dari komitmen dua sekolah ini adalah nilai UN di SMKS-A lebih tinggi dibandingkan SMKS-B, sedangkan prestasi siswa dalam hal ketrampilan menunjukkan SMKS-B lebih unggul. Pada sekolah yang telah mapan, SMKN telah mampu memadukan prestasi dalam hal nilai UN dengan prestasi ketrampilan siswa dan juga prestasi non akademik lainnya.

Bentuk komitmen dari kepala sekolah terhadap proses perubahan di SMKS-A adalah kepala sekolah ikut allout dalam pelaksanaan program peningkatan nilai UN, memberikan konseling pada siswa untuk meningkatkan motivasi dan usaha belajarnya. Hal ini dikarenakan kepala sekolah memiliki latar belakang sarjana psikologi dan mengampu program bimbingan konseling. Pada jam pelajaran bimbingan dan konseling juga diberikan sosialisasi tentang perubahan target nilai UN beserta program yang direncanakan.

Kepala SMKN memiliki bentuk komitmen lain yakni dengan memberikan 
rewards pada siswa dan guru yang meraih target. Target bagi siswa yang mendapatkan rewards adalah nilai 10, rewards yang diberikan adalah ucapan selamat dan terima kasih serta uang sebesar Rp.50.000 per mata pelajaran. Jadi misalnya siswa mendapatkan nilai 10 untuk dua mata pelajaran maka total akan mendapatkan uang Rp100.000. Rewards yang diberikan pada guru adalah ucapan selamat dan terima kasih yang diberikan pada forum evaluasi atau briefing.

Nilai UN yang paling tinggi dicapai oleh SMKN merupakan hasil tradisi prestasi yang kuat dan telah berlangsung selama bertahun-tahun. Selain itu, input siswa yang masuk ke sekolah ini disaring. Dari 343 pendaftar tahun 2013, diambil 277 orang siswa baru yang diterima untuk belajar di SMKN. Sementara sekolah lain tidak menyeleksi siswa dan bahkan kekurangan siswa.

Selain faktor dari input siswa, ada faktor lain yakni persiapan. Di SMKS-B mereka mengakui kurangnya persiapan dalam melakukan perubahan. Persiapan yang dianggap kurang itu salah satunya dari adanya tambahan pelajaran untuk mata pelajaran yang di-UN-kan yang dimulai pada bulan Januari, padahal sekolah yang lain sudah mulai pada bulan November yakni setelah para siswa kembali dari praktek industri.

Komitmen yang kuat dari kepala sekolah juga dapat memberikan pengaruh pada pencapaian prestasi siswa. Komitmen dari kepala sekolah diwujudkan dalam bentuk membangkitkan motivasi bagi siswa untuk belajar lebih tekun dan meningkatkan motivasi guru untuk mencapai target. Untuk menjaga motivasi siswa dan meningkatkan efektivitas belajar maka sekolah memanggil guru dari luar sekolah (tentor) untuk memberikan materi, trik, dan tips untuk mengerjakan soal-soal UN. Hasil dari komitmen kepala sekolah ini dapat terlihat pada nilai UN yang dicapai siswa. SMKS-A baru beroperasi resmi tahun 2008 tetapi memiliki rata-rata nilai UN lebih tinggi dibandingkan SMKS-B yang telah berdiri tahun 1986.
Jumlah siswa di sekolah yang sudah mapan relatif stabil dari tahun ke tahun. Pada sekolah swasta yang memiliki akreditasi A jumlah siswa cenderung mengalami kenaikan dari tahun ke tahun. Hal ini menunjukkan bahwa kepercayaan masyarakat terhadap sekolah cenderung mengalami kenaikan dari tahun sebelumnya.

Visi sekolah akan bermanfaat untuk pengelolaan perubahan. Visi merupakan panduan bagi warga sekolah untuk menjalankan atau memfokuskan kegiatan. Pengelolaan yang terbagi menjadi tahapan unfreeze, changing, dan refreeze membutuhkan skill, insentif, sumber daya, dan program. Visi, skill, dan sumber daya akan bermanfaat pada penyusunan strategi yang dipilih pimpinan. Peranan pimpinan adalah menggunakan dan meningkatkan skill para staf, mendayagunakan insentif dan sumber daya, menetapkan dan mengendalikan program. Peranan guru dan siswa adalah ikut mensukseskan program dan melaksanakan kegiatan siswa.

Hambatan yang dialami meliputi dari aspek: skill, insentif, sumber daya, dan program. Hambatan skill yakni belum semua guru memiliki sertifikat pendidik, adanya guru yang memiliki nilai PKG kurang terutama nilai kompetensi pedagogis yang kurang. Insentif yang diberikan oleh sekolah pada guru dinilai masih kurang sehingga menjadikan proses perubahan menjadi lamban. Sumber daya yang dimiliki oleh sekolah swasta yakni fasilitas pembelajaran masih kurang sehingga proses pembelajaran kurang bervariasi. Hambatan juga berasal dari pelaksanaan kegiatan siswa.

Pembahasan

\section{Pengelolaan Tahap Perubahan}

Perubahan perlu dikelola agar dapat berjalan sesuai dengan harapan stakeholders. Perubahan target mutu pendidikan perlu diikuti dengan upaya konkrit dari pimpinan supaya target yang telah ditetapkan dapat tercapai. Jika target yang ditetapkan tidak diupayakan dengan serius dan tidak berhasil dicapai maka artinya kinerja pimpinan tidak memuaskan. 
Ada target yang tercapai dan tidak tercapai. Pada target yang tidak tercapai evaluasi yang dilakukan sekolah adalah dengan mempersiapkan dengan lebih baik lagi pada tahun berikutnya. Dengan kata lain, sekolah melakukan perbaikan proses untuk tahun berikutnya. Proses yang dilakukan adalah dengan memperpanjang masa persiapan untuk melaksanakan UN.

Peningkatan mutu memerlukan adanya pengembangan organisasi. Hal ini juga terjadi di SMKN, dimana pengembangan organisasi dilakukan dengan membuat wakil kepala sekolah bidang sumber daya manusia dan mengembangkan sekolah menjadi 14 unit kerja. Selain itu, ada pengembangan kapasitas kepemimpinan guru. Hal ini mendukung teori dalam pengembangan organisasi. Jumlah guru yang banyak, membutuhkan wahana untuk aktualisasi diri staf. Jumlah guru di SMKN sebanyak hampir 70 orang. Layak lah kiranya kemudian sekolah ini membentuk 14 unit kerja yang membantu kepala sekolah menjalankan tugas-tugas administratif pengelolaan sekolah.

Pada sekolah yang telah mapan, pengembangan kapasitas (capacity building) sudah optimal. Para guru yang diserahi tugas untuk menjalankan tanggung jawab dapat menjalankan dengan baik. Pembagian kewenangan/tugas terdesentralisasi dan terorganisir dengan baik. Salah satu penyebabnya adalah karena perbedaan gaji yang tidak terlalu jauh antara kepala sekolah dengan guru. Pada sekolah yang kecil, pembagian kerja belum terlalu terlihat, masih principal centered. Segala macam urusan pimpinan dikerjakan oleh kepala sekolah. Ini juga untuk mengamankan posisinya. Untuk membuktikan hanya kepala sekolah saja yang mampu melakukan/menyelesaikan pekerjaan pimpinan. Ini seperti darah biru dalam sistem monarkhi absolut, dimana hanya yang berdarah biru yang berhak menjadi pemimpin.

Konsep ini dinamakan dengan distributed leadership, yakni membagi-bagikan tugas kepemimpinan pada warga sekolah khususnya guru. Konsep ini didukung oleh Bass \& Bass (2008) yang mengatakan bah- wa pemimpin di suatu kelompok itu bisa berganti-ganti sesuai dengan perannya di kelompoknya. Tujuan kepemimpinan di sekolah adalah untuk membangun sekolah melalui bekerja bersama, membuat makna dan pengetahuan secara kolektif dan kolaboratif (Lambert 1998 dalam Harris, 2003, p. 75). Konsep ini tidak lepas dari kapasitas sekolah (school capacity). Kapasitas sekolah adalah kemampuan sekolah untuk mengembangkan diri agar dapat menangani urusannya dengan lebih baik. Konsep-konsep ini sangat cocok dikembangkan untuk sekolah karena mereka menggunakan model manajemen berbasis sekolah.

Konsep pengembangan organisasi dan distributed leadership relevan dengan multilevel pengelolaan sekolah seperti dikemukakan (Cheng, 1996, p. 90). Dalam multilevel pengelolaan sekolah, outcome sekolah dihasilkan dari outcome kelompok, dan outcome kelompok dihasilkan dari outcome individu. Pola pikir ini dapat juga dibalik, dimana prestasi sekolah dihasilkan dari prestasi kelompok, sedangkan prestasi kelompok dihasilkan dari prestasi individu-individu. Berdasarkan konsep ini, maka dalam pengelolaan suatu perubahan perlu membebankan target pada individu atau kelompok. Hasil prestasi individu atau kelompok akan menghasilkan prestasi sekolah. Untuk melakukan pengembangan organisasi maka diperlukan kemampuan distributed leadership. Ini akan berimplikasi pada pemberdayaan warga sekolah untuk mencapai target-target individual.

Kepala sekolah di sekolah swasta kadang harus merangkap sebagai Kepala tata usaha (TU), bahkan menjadi staf TU, dan guru, selain sebagai pimpinan sekolah. Hal ini dilakukan karena kekurangan tenaga administrasi sehingga pekerjaan administrasi harus dibantu guru dan kepala sekolah. Hal ini berbeda dengan guru di sekolah negeri dimana ada pegawai TU yang jumlahnya cukup untuk membantu tugastugas guru dan pimpinan sekolah dalam administrasi.

Langkah peningkatan mutu disesuaikan dengan perubahan yang ada di tingkat nasional, salah satunya adalah adanya 
program sertifikasi guru. Program sertifikasi guru mengarah pada penerapan merit system dalam kepegawaian. Ada rewards bagi guru yang dinilai memiliki kinerja yang baik, dan yang tidak baik sehingga harus mendapatkan hukuman. Salah satu bentuk hukuman adalah tidak diberi jam yang cukup bagi guru tertentu yang berakibat pada tidak turunnya tunjangan sertifikasi.

Selain insentif dalam bentuk materi, guru juga sudah merasa diberi penghargaan oleh sekolah dalam bentuk lain sehingga mampu bekerja lebih efektif. Hasil ini sesuai dengan penelitian Altunay, Arli, \& Yalçinkaya (2012) dimana tim-tim di sekolah yang diberi penghargaan bekerja lebih efektif dibandingkan tim-tim di sekolah yang tidak diberi penghargaan (awards).

Pengelolaan perubahan di sekolah seperti uraian artikel ini mendukung penelitian sebelumnya. (Darmadji, 2008) meneliti perkembangan Mayoga juga menyimpulkan bahwa sebelum menjadi MAN unggulan, pengelolaan Mayoga masih konvensional sentralistik, berorientasi pada juklak, juknis, serta instruksi atasan, penempatan guru masih bersifat kekronian sehingga terjadi guru mismatch. Dengan kondisi yang konvensional semacam itu, Mayoga dahulu bukanlah sekolah yang dianggap memiliki mutu oleh masyarakat. Kemudian terjadilah pembenahan mutu sehingga sedikit demi sedikit masyarakat mengakui Mayoga sebagai MAN Ungggulan. Upaya yang dilakukan oleh manajemen madrasah adalah dengan penerapan total quality assurance dan total quality control, pengembangan lembaga dan struktur mayoga, pendelegasian kewenangan dan pengambilan keputusan serta "kebebasan" warga sekolah untuk memajukan sekolah. Empat konsep terakhir identik dengan konsep-konsep: distributed leadership, instructional leadership, teacher leadership, building capacity, school improvement seperti dikemukakan (Harris, 2003).

Apa yang dilakukan oleh Mayoga ini juga peneliti lihat dilakukan di SMKN. Hanya saja, SMKN masih berorientasi pada juklak, juknis, serta instruksi atasan, dan secara sejarah memang sudah memiliki tradisi yang panjang dalam kualitas pendi- dikan. Dua sekolah yang lain yakni SMKSA dan SMKS-B belum memiliki prestasi yang konsisten. Meski demikian, SMKS-B sebenarnya sudah berusia cukup tua karena sudah beroperasi sejak 1986 sedangkan SMKS-A baru menerima siswa tahun 2009.

Sekolah SMKS-A sebenarnya sejak dari hari kelahirannya dicanangkan sebagai sekolah unggulan, akan tetapi sampai saat ini belum tercapai dan jumlah siswa per rombongan belajar sekitar 10 siswa. Jumlah rombongan belajar per program keahlian yang diselenggarakan hanya satu kelas. Dengan jumlah siswa yang diterima sedikit, sulit untuk dapat meningkatkan mutu siswa karena terbatasnya program yang dapat dilakukan. Sebagai contoh misalnya di SMKN, dengan jumlah siswa banyak maka kebutuhan akan guru juga meningkat, jumlah dana yang didapatkan sekolah juga meningkat sehingga dapat merekrut guru-guru yang memiliki nilai PKG yang bagus, mengembangkan laboratorium yang lengkap. Siswa dan guru yang banyak jumlahnya akan membuat pengembangan organisasi, struktur, dan strategi pengembangan sekolah menjadi lancar.

Sekolah harus menjamin bahwa organisasinya merupakan organisasi yang "total" dalam kalimat total quality management. Artinya, semua warga sekolah wajib untuk bekerja secara sinergis dan menemukan tujuan yang sama. Tujuan pribadi harus dikorbankan untuk menjadi tujuan sekolah. Dalam pengembangan organisasi, guru yang ditugasi harus didukung oleh semua warga sekolah tanpa terkecuali. Ini yang mulai berhasil diterapkan oleh SMKN. Hal ini sesuai dengan pendapat West-Burnham (1997, p.32) yang menjelaskan kualitas terpadu memiliki komponen prinsip-prinsip, proses-proses, orang-orang, dan pencegahan.

Komponen yang penting dalam kualitas adalah pencegahan. Bagaimana sebelum terjadinya kerusahan atau kesalahan itu bisa dibetulkan atau dicegah. Hal ini sudah dilakukan dengan baik oleh SMKN yang melakukan pencegahan bagi guru yang tidak favorit untuk mengajar kelas XII yang akan menghadapi UN. Guru yang 
nilai PKG-nya rendah juga tidak dipilih untuk mengajar, yang merupakan salah satu bentuk pencegahan dalam konteks kualitas terpadu.

\section{Strategi yang Digunakan}

Hasil penelitian ini menunjukkan adanya perubahan merupakan hasil konsensus dari warga sekolah. Adanya konsensus tersebut menunjukkan bahwa tidak ada paksaan bagi warga sekolah dari pimpinan sekolah terhadap suatu target perubahan. Semua sekolah menggunakan strategi kombinasi rasional, yakni tidak dengan cara memaksa untuk berubah. Strategi perubahan dilakukan dengan rational and power sharing. Konsep ini saling terkait dengan strategi kepemimpinan transformasional yakni memberi pertimbangan secara rasional dan memberdayakan warga sekolah agar mereka mau berkontribusi terhadap peningkatan mutu sekolah. Komponen dalam kepemimpinan transformasional seperti: kharisma, pertimbangan individual, maupun stimulasi intelektual sangat cocok digunakan untuk sebagai sarana dalam melakukan pemberdayaan pada staf/karyawan.

Strategi empiris rasional serta rational and power sharing dikembangkan tetapi dengan tetap tegas terhadap warga sekolah. Setelah konsensus didapatkan, maka kepala sekolah bertugas untuk mengamankan konsensus itu. Hal ini membuat tidak ada peluang bagi warga sekolah yang menolak perubahan untuk tidak mendukung karena sudah sesuai konsensus. Pada tahap ini, kepala sekolah sudah bertindak tegas pada guru yang tidak mendukung program. Semua warga sekolah harus mendukung program yang telah dirumuskan.

Strategi empiris rasional adalah sesuai dengan karakteristik sekolah sebagai learning organization. Karakteristik sebagai learning organization ini sudah dilaksanakan sekolah dengan adanya pengembangan profesionalisme guru. Guru dituntut untuk terus menerus belajar guna menghadapi situasi kelas yang terus berubah. Guru tidak dapat berhenti belajar karena harus dapat menyesuaikan diri dengan perkembangan.
Faktor guru merupakan faktor kunci dalam peningkatan mutu khususnya aspek kompetensi pedagogik maupun kompetensi profesional.

\section{Upaya Mengatasi Hambatan}

Proses perubahan di sekolah minim akan resistensi. Jika pun ada resistensi, hal itu tidak menghalangi proses eksekusi program secara signifikan. Bahkan mereka ikut berubah juga meski resisten terhadap perubahan. Hal ini disebabkan karena aktor informal leader dan guru telah dilibatkan dalam proses perencanaan program/perubahan. Ini berbeda dengan penelitian (Berkovich, 2011) yang meneliti pemogokan mengajar guru di Israel karena tidak dilibatkan dalam proses perencanaan program/kebijakan. Pelibatan warga sekolah dalam proses perencanaan akan meningkatkan kepuasan kerja staf dan keterlibatannya dalam eksekusi kegiatan.

Meski minim resistensi, akan tetapi ada sebagian kecil guru yang menolak perubahan, bahkan menghalangi perubahan. Ada guru yang tidak mau dituntut untuk berubah karena nyaman dengan situasi sekarang dan mengajak guru lain untuk tidak ikut berubah atau nggondeli. Kondisi ini menuntut pimpinan untuk memberi perhatian khusus pada individu. Hal ini diperkuat oleh pendapat Muhyadi (2010, p. 10) menyatakan "kunci keberhasilan perubahan terletak pada level individu. Implikasinya, setiap orang harus diyakinkan akan pentingnya perubahan sehingga secara individual mereka memahami dan mendukung program perubahan yang dirancang oleh pimpinan".

Hasil penelitian juga menunjukkan bahwa komunikasi menjadi faktor keberhasilan perubahan. Hasil ini didukung oleh Kasali (2005, p. 12) bahwa komunikasi adalah faktor penting untuk meredakan atau menghilangkan resistensi. Persepsi guru tentang sesuatu perubahan harus sama dengan pimpinan karena dengan kesamaan persepsi maka akan dicapai kesamaan usaha untuk mencapai tujuan. Hal ini dikenal sebagai organisasi yang total dalam total quality management. 
Kegagalan mencapai target yang ditetapkan salah satunya disebabkan guru bahwa intake (input) siswa sangat menentukan hasil. Pendapat ini bertentangan dengan pola pikir sistem yang menganggap proses yang baik akan dapat memperbaiki output meski dengan input yang kurang. Sebagian guru menganggap bahwa kedisiplinan dan komitmen dari guru dan siswa menjadi faktor sukses pencapaian perubahan. Meski demikian, komitmen perlu diimbangi dengan teknik/strategi pembelajaran agar target tercapai. Hal ini terlaksana di SMKN dimana mereka melakukan tutor teman sebaya. Tutor ini diakui oleh siswa cukup efektif untuk menyelesaikan soal-soal yang tidak diketahuinya, akan tetapi proses belajar kelompok di sekolah dan di rumah tidak berjalan dengan baik sehingga kurang menghasilkan hasil yang maksimal. Sebaiknya proses ini dijalankan dengan maksimal lagi supaya didapatkan hasil yang maksimal juga.

\section{Simpulan}

Berdasrkan hasil penelitian dan pembahasan dapat disampaika simpulan sebagai berikut. Pengelolaan perubahan pada proses perencanaan, pengorganisasian, penggerakan, pengontrolan, dan pengevaluasian menjadi tugas utama/tanggung jawab wakil kepala sekolah bidang kurikulum beserta tim. Pada tahap unfreeze diisi dengan kegiatan kepala sekolah beserta tim sekolah yang melakukan sosialisasi pentingnya perubahan. Tahap changing diisi dengan program-program peningkatan target nilai UN yakni: pemberian penambahan materi tiga pelajaran, tryout UN, melakukan achievement motivation training, dan program tutor teman sebaya. Tahap refreezing diisi dengan pemberian rewards berupa apresiasi maupun syukuran dari sekolah untuk tim yang terlibat dalam proses perubahan. Strategi yang digunakan adalah empiris rasional dan power sharing dengan kebijakan pengembangan profesionalisme guru.

Nilai-nilai yang dinyakini sebagai kesuksesan dalam keberhasilan perubahan adalah kedisiplinan guru dan siswa, moti- vasi guru dan siswa, komitmen guru dan siswa, budaya akademik yang terjaga. Sekolah SMKS tidak sekedar mendidik siswa dari akademis saja, tetapi membekali secara akhlaq dan budaya islami. Sekolah yang ingin menanamkan budaya leluhur dengan membekali lulusannya dengan budaya Jawa yang menjadi akar budaya di wilayah DIY.

Berdasarkan simpulan yang disajikan, maka dapat disampaikan saran sebagai berikut.

Mengingat target peningkatan mutu adalah tugas berat maka diperlukan kreativitas dalam proses pembelajaran. Kepala sekolah/pimpinan perlu memperbanyak dan mempercepat adopsi inovasi pembelajaran yang cocok dengan kondisi sekolah. Hal ini terkait juga dengan pengembangan profesionalisme guru melalui berbagai pendidikan dan latihan untuk meningkatkan mutu pembelajaran.

Sekolah perlu mendorong siswa untuk terus belajar secara mandiri baik di dalam atau luar kelas. Oleh karena itu dapat terus dikembangkan tutor teman sebaya, belajar kelompok, maupun penyediaan materi pembelajaran dengan resources learning. Penerapan teknik pembelajaran ini perlu terus dipantau dan dikendalikan agar tercapai efektivitasnya.

\section{Daftar Pustaka}

Altunay, E., Arli, D., \& Yalçinkaya, M. (2012). A Qualitative Study on Change Management in Primary Schools Award Winning and Non-Award Winning Schools Case in Study of TQM. Ducational Sciences: Theory $\mathcal{E}$ Practice, 2(12), 725-730.

Barney, J. B. (1995). Looking inside for Competitive Advantage. The Academy of Management Executive (1993-2005), 9(4), 49-61. Retrieved from http://www.jstor.org/stable/4165288

Bass, B. M., \& Bass, R. (2008). The bass handbook of leadership: Theory, research, and managerial applications. New York: Free Press. 
Berkovich, I. (2011). No we won't! Teachers' resistance to educational reform. Journal of Educational Administration, 49(5), 563-578.

Cheng, Y. C. (1996). School effectiveness and school-based management. London: Falmer Press.

Creasey, T. (2007). Defining change management. Retrieved January 26, 2015, from www.changemanagement.com

Creswell, J. W. (2012). Educational research: Planning, conducting, and evaluating. Quantitative and qualitative research (3rd ed.). New Jersey: Pearson Education Inc.

Darmadji, A. (2008). Evaluasi program MAN model sebagai upaya peningkatan mutu madrasah aliyah. Disertasi. Universitas Negeri Yogyakarta.

Goksoy, S. (2013). The role of the educational manager's in the management of change. International Journal of Academic Research, 5(6).

Harris, A. (2003). Teacher leadership and school improvement. In A. Harris, D. Hopkins, A. Hargreaves, \& C. Chapman (Eds.), Effective leadership for school improvement. New York: Taylor \& Francis Group.

Kasali, R. (2005). Change! Jakarta:

Gramedia.
Menteri Pendidikan Nasional. Peraturan pemerintah republik indonesia nomor 19 tahun 2005 tentang standar nasional pendidikan (2005).

Menteri Pendidikan Nasional. Peraturan Menteri Pendidikan Nasional Republik Indonesia Nomor 19 Tahun 2007 tentang Standar Pengelolaan Pendidikan oleh Satuan Pendidikan Dasar dan Menengah (2007).

Muhyadi. (2010). Manajemen perubahan. In Workshop Strategi Pengembangan Mutu Sekolah. Program Pascasarjana UNY.

Mulyadi. (1997). Manajemen perubahan. Jurnal Ekonomi Dan Bisnis Indonesia, 12(3).

Porter, M. E. (1996). What is strategy? Harvard Business Review, 61-78.

Usman, H. (2006). Manajemen: Teori praktik dan riset pendidikan. Jakarta: Bumi Aksara.

West-Burnham, J. (1997). Managing quality in schools: effective strategies for qualitybased school improvement (schools management solutions). London: Prentice Hall.

Zamroni. (2007). Meningkatkan mutu sekolah, teori, strategi dan prosedur. Jakarta: PSAP Muhammadiyah. 